\title{
A HLH is a rare fatal condition easily misdiagnosed as infectious disease
}

\section{Md. Khaja Moinuddin*, Premalatha R.}

Department of Pediatrics, Bangalore Medical College and Research Institute (BMCRI), Bangalore, Karnataka, India

Received: 28 February 2017

Revised: 10 April 2017

Accepted: 22 April 2017

\section{*Correspondence:}

Dr. Md. Khaja Moinuddin,

E-mail: docmoinuddin@gmail.com

Copyright: () the author(s), publisher and licensee Medip Academy. This is an open-access article distributed under the terms of the Creative Commons Attribution Non-Commercial License, which permits unrestricted non-commercial use, distribution, and reproduction in any medium, provided the original work is properly cited.

\begin{abstract}
Hemophagocytic lymphohistiocytosis (HLH) is characterized by clonal proliferation of the morphologically normal antigen processing cells, i.e. macrophages and CD8 lymphocytes in the involved tissue, due to uncontrolled activation of inflammatory cytokines. Two major forms include Familial HLH and infection associated hemophagocytic syndrome. Both these forms of HLH proceed with a generalized disease process i.e. fever, rashes and weight loss. Hence it is easily misdiagnosed as any infectious disease. So, a high index of suspicion is required for the diagnosis. With the help of clinical and laboratory criteria we can easily diagnose it without any genetic testing.
\end{abstract}

Keywords: Bone marrow, Hemophagocytic lymphohistiocytosis, Macrophages

\section{INTRODUCTION}

Hemophagocytic lymphohistiocytosis (HLH) is characterized by clonal proliferation of the morphologically normal antigen processing cells, i.e. macrophages and CD8 lymphocytes in the involved tissue, due to uncontrolled activation of inflammatory cytokines. ${ }^{1} \mathrm{HLH}$ is a syndrome characterized by fever, rashes, weight loss, pancytopenia, splenomegaly, and hemophagocytosis in bone marrow, liver, or lymph nodes. It can be classified as familial or acquired HLH.

Acquired HLH is associated with severe viral, bacterial, fungal and parasitic infections and also autoimmune diseases and malignancies. It is also associated with high mortality if not treated early. HLH needs to be differentiated from other conditions like Sepsis, SIRS, MODS and Macrophage activation syndrome which can mimic HLH, as the management stratergies and outcome of each differ according to the etiology. ${ }^{2}$ Diagnosis rests on the basis of a molecular genetic defect or presence of any 5 of the 8 clinco-pathological criteria, given in Table $1 .^{3}$
Table 1: Clinic-pathological criteria.

\begin{tabular}{|c|c|}
\hline \multicolumn{2}{|c|}{ Diagnostic criteria for HLH } \\
\hline \multicolumn{2}{|c|}{ 1. A molecular diagnosis consistent with HLH or } \\
\hline \multicolumn{2}{|c|}{$\begin{array}{l}\text { 2. Diagnostic criteria for HLH fulfilled } 5 \text { out of } 8 \\
\text { criteria presents }\end{array}$} \\
\hline Madness & $24(21.6 \%)$ \\
\hline \multirow{2}{*}{ Clinical criteria } & Fever \\
\hline & Splenomegaly \\
\hline \multirow[b]{2}{*}{ Laboratory criteria } & Cytopenias \\
\hline & $\begin{array}{l}\text { Hypertriglyceridemia } \\
\text { and/or hypofibrinogenemia }\end{array}$ \\
\hline $\begin{array}{l}\text { Histopathological } \\
\text { criteria }\end{array}$ & $\begin{array}{l}\text { Hemophagocytosis in bone } \\
\text { marrow or spleen or lymph } \\
\text { node. No evidence of } \\
\text { malignancy }\end{array}$ \\
\hline \multirow{3}{*}{ New diagnostic criteria } & $\begin{array}{l}\text { Low or absent NK-cell } \\
\text { activity }\end{array}$ \\
\hline & Ferritin $>500$ microgram $/ 1$ \\
\hline & Soluble CD25 >2400U/ml \\
\hline
\end{tabular}




\section{CASE REPORT}

1 year 6month old male child born out of non consanguinity, was admitted in our hospital with history of fever since 6 months, abdominal distension since 3 months, multiple swellings in neck and inguinal region since 3 months, progressive pallor since 3 months and rashes since 4 days, O/E irritable, severe pallor+, multiple lymph nodes were palpable in neck, axilla and inguinal region non tender firm in consistency, erythematous macular rashes were presentt all over the body.

P/A distension +ve, no free fluid, spleen is palpable, $7 \mathrm{~cm}$ below the left costal margin, firm in consistency and liver is palpable with a span of $9 \mathrm{~cm}$, other systems were normal.

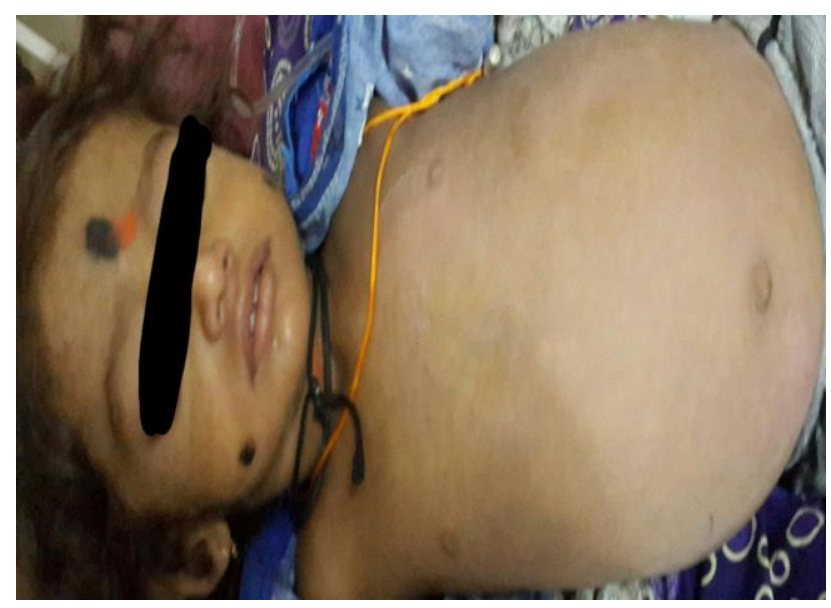

Figure 1: Rashes and abdominal distention.

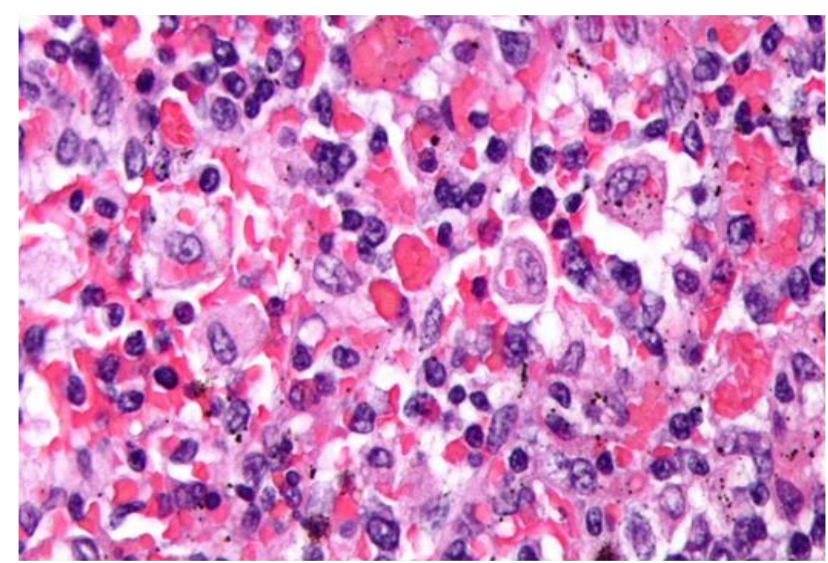

Figure 2: Bone marrow smear showing Hemophagocytosis.

$\mathrm{Hb}$ - 7.2, wbc count-24000, plt - 56000, ESR- 70, mantoux test- negative, sputum for AFB- negative, peripheral smear- microcytic hypochromic anemia with leucocytosis no blast cells, reticulocyte count - $2 \%$, LDH$848 \mathrm{U} / \mathrm{L}$ triglycerides $525 \mathrm{mg} / \mathrm{dl}$, ferritin $-662 \mathrm{ng} / \mathrm{dl}$, fibrinogen - 53ng/dl, INR - 4.3, USG Abdomen hepatosplenomegaly with mesentric lymphadenopathy, FNAC of lymph node - immunoblasts with histiocytic aggregates, Bone marrow - reactive marrow with hemophagocytosis. no evidence of leukemia in the smear.

\section{DISCUSSION}

Hemophagocytic lymphohistiocytosis syndrome, which has also been referred to as histiocytic medullary reticulosis, was first described by Scott and Robb-Smith in $1939 .{ }^{4}$ It is characterized by fever, rashes, weight loss, pancytopenia, splenomegaly, and hemophagocytosis in bone marrow, liver, or lymph nodes. ${ }^{5}$ It includes common features of cytopenias, hypercytokinaemia, haemophagocytosis, hyperferritinaemia, variable hypofibrinogenaemia, multi-organ failure and very often death. ${ }^{5}$ The overlap between HLH and sepsis syndrome is also known. ${ }^{6}$ Initially suspected as malignancy on investigation, $\mathrm{CBC}$ showed low $\mathrm{Hb}$ and Platelets and elevated TLC Blood culture was sent antibiotics were started and tubercular work up done. FNAC of lymph node showed Hemophagocytes as suspected in HLH and other workup was also done subsequently.

On the basis of Clinical and laboratory findings fulfilling the HLH criteria, we made diagnosis of HLH and started treatment according to HLH protocol. ${ }^{7}$

Index case presented with eight criteria in the form as follows.

- Fever

- Splenomegaly

- Cytopenias

- Hypertriglyceridemia

- hypofibrinogenemia

- Hemophagocytosis in bone marrow

- Hemophagocytosis in lymph node

- Elevated ferritin

The poor prognosis of this syndrome suggests that patients should be treated initially with combination of chemotherapy and immunotherapy, regardless of whether they are thought to have familial HLH. Chemotherapy with etoposide, Anti thymocyte globulin (ATG), dexamethasone, cyclosporine $\mathrm{A}$ is recommended, with the use of intrathecal methotrexate in patients who have neurologic symptoms or persistent cerebrospinal fluid abnormalities. ${ }^{7}$ According to HLH 2004 protocols 8 weeks of therapy is given for secondary non-genetic disease and for genetic disease therapy should be continued even after 8th week until Stem cell transplantation is completed.

Sporadic HLH carries a better prognosis. HLH triggered by bacterial infection is associated with a high recovery rate. The condition may mimic a number of systemic infections. Appropriate broad-spectrum antibiotics and supportive therapy should be given. Early recognition and treatment with chemotherapeutic agents or bone marrow transplant may reduce mortality. ${ }^{7}$ 


\section{CONCLUSION}

Authors recommend high index of suspicion for diagnosing HLH amongst patients presenting with fever and cytopenia, it is commonly misdiagnosed as an infection or any malignancy.

Funding: No funding sources

Conflict of interest: None declared

Ethical approval: Not require

\section{REFERENCES}

1. Kliegman RM, Stanton BF, St. Geme JW, Nelson N, Textbook of Paediatrics First South Asia Edition, Chapter 507, 2016:2484-249.

2. Castillo L, Carcillo J. Secondary hemophagocytic lymphohistiocytosis and severe sepsis/ systemic inflammatory response syndrome/ multiorgan dysfunction syndrome/macrophage activation syndrome share common intermediate phenotypes on a spectrum of inflammation. Pediatr Crit Care Med. 2009;10:387-92.

3. Jan-Inge H, AnnaCarin H, Maurizio A, Egeler RM, Filipovich AH, Imashuku S, et al. HLH-2004:
Diagnostic and Therapeutic Guidelines for Hemophagocytic Lymphohistiocytosis, 2006 WileyLiss, Inc.

4. Scott R, Robb Smith A. Histiocytic medullary reticulocytosis. Lancet 1939;2:194-8.

5. Fisman DN, Hemophagocytic Syndromes and Infection.Emerging infectious diseases. 2000;6:6018.

6. Raschke RA, Garcia-Orr R. Hemophagocytic Lymphohistiocytosis A Potentially Underrecognized Association With Systemic Inflammatory Response Syndrome, Severe Sepsis, and Septic Shock in Adults. Chest. 2011;140:933-8.

7. Henter JI, Horne A, Arcio M. HLH 2004, Diagnostic and therapeutic guidelines for Hemophagocytic Lymphohistiocytosis. Pediatric Blood Cancer. 2007;48:124-31.

Cite this article as: Moinuddin MK, Premalatha R. A HLH is a rare fatal condition easily misdiagnosed as infectious disease. Int J Contemp Pediatr 2017;4:1529-31. 